\title{
Octocorals (Alcyonacea and Pennatulacea) from Paleogene deep-water strata in western Washington State, USA
}

\author{
James L. Goedert, ${ }^{1 *}$ ๑ Lloyd S. Guthrie, ${ }^{2}$ and Steffen $\mathrm{Kiel}^{3} \odot$ \\ ${ }^{1}$ Burke Museum of Natural History and Culture, University of Washington, Seattle, Washington 98195, USA <jamesgoedert@outlook.com> \\ ${ }^{2} 5127$ Herron Street NE, Lacey, Washington 98516, USA <lloyd_guthrie@msn.com> \\ ${ }^{3}$ Swedish Museum of Natural History, Department of Palaeobiology, Box 50007, 10405 Stockholm, Sweden <Steffen.Kiel@nrm.se>
}

\begin{abstract}
The fossil record of octocorals from Cenozoic marine strata of western North America is quite limited, and they have not been reported previously from rocks in Washington State, USA. Two late Oligocene specimens from the upper part of the Lincoln Creek Formation in western Washington, referred to Radicipes? sp., are the first fossil record of the family Chrysogorgiidae. The family Isididae is represented by an internode and two holdfasts identified as Isidella sp. collected from the Oligocene Pysht Formation, along with specimens questionably identified as Lepidisis sp., possibly the first fossil record for this genus. Together, these are the first confirmed fossils of the Alcyonacea from north of California in western North America. The axes of sea pens from several late Eocene or early Oligocene localities in the Lincoln Creek Formation in the central part of western Washington, and the Pysht and Makah formations on the north side of the Olympic Peninsula, are the first fossil record for the Pennatulacea from western North America; all are tentatively referred to the genus 'Graphularia'. Large axes from the Lincoln Creek Formation and Makah Formation are referred to 'Graphularia' (?) aff. sasai, because they are similar to the species known only from late Eocene and early Oligocene rocks in Japan.
\end{abstract}

\section{Introduction}

Cenozoic fossils of octocorals, primarily bamboo corals but also sea pens, have long been recognized from many parts of the world (e.g., Europe: Nielsen, 1917; Bałuk and Pisera, 1984; Langer, 1989; Lauridsen and Bjerager, 2014; Australia and New Zealand: McCoy, 1877; Tate, 1877; Squires, 1958; Eagle, 2007; and eastern North America: Hickson, 1938; Shapiro and Ramsdell, 1965; Kocurko, 1993, and references therein). Overall, however, the fossil record of octocorals is relatively poor.

The oldest unequivocal Cenozoic octocoral fossils from western North America and the North Pacific Basin are from rocks of latest Paleocene or earliest Eocene age in the upper part of the Santa Susana Formation in the Simi Valley, southern California, that were identified by Squires (1999) as ?Mopsea sp., aff. M. costata Milne-Edwards and Haime, 1850. This is the only previous fossil record of the family Isididae Lamouroux, 1812, from western North America. Squires and Demetrion (1992) reported two octocorals from shallow-marine Eocene (51-52 Ma) strata of the Bateque Formation in Baja California Sur, Mexico. These fossils were identified as Heliopora? sp. (Family Helioporidae Moseley, 1876) and Parisis batequensis Squires and Demetrion, 1992 (Family Parisididae Aurivillius, 1931). A small fossil questionably identified (Armentrout, 1974) as ?Callogoria [sic] sp. (=Callogorgia Gray, 1870;

\footnotetext{
*Corresponding author.
}

Family Primnoidae Milne-Edwards, 1857) from the late Oligocene uppermost part of the Lincoln Creek Formation, Canyon River, Washington, has not been formally published, and we have been unable to further evaluate the record.

Nomland (1916) reported a 'gorgonian' fragment from possibly earliest Eocene rocks at Marysville Buttes, California; however, no specimen number was given, although Nomland stated that the specimen, from "locality 1853," is in the collections at the University of California (Berkeley); nobody has mentioned the specimen since. Nomland (1916) also reported a 'gorgonian' octocoral fragment from Miocene rocks of the Astoria Formation at Astoria, Oregon, although it is difficult to tell from the illustrations whether this identification is correct. Nomland (1916) did not note a specimen number or repository for the specimen, although he did state that it was from California Academy of Sciences loc. 172. In a detailed monograph of the paleontology of the Astoria Formation, Moore (1963) noted other corals from the Astoria Formation, but she made no mention of the possible octocoral fossil discussed by Nomland (1916).

Fossils of sea pens, pennatulaceans, are represented most often by the central or axial rod, which calcifies in some taxa and have been found in many parts of Europe and elsewhere (e.g., McCoy, 1877; Squires, 1958; Reich and Kutscher, 2011, and references therein), but have not been reported previously from western North America. From the North Pacific Basin, there are Cretaceous sea pen fossils from the Magellan Seamounts (Mel'nikov et al., 2006; Zakharov et al., 2007) and only two Cenozoic records of pennatulacean fossils, both from 
Japan. Fossils of large pennatulacean axial rods from late Eocene or early Oligocene strata in Hokkaido were described by Yabe (1955), and an axial rod was described from Pleistocene rocks in Tokyo (Yabe and Sugiyama, 1937).

The purpose of this paper is to record fossils of octocorals from Paleogene rocks in Washington State (Fig. 1), including the first fossil record for the family Chrysogorgiidae Verrill, 1883, and first reported pennatulacean (sea pen) fossils from western North America.

\section{Geological setting and paleoecology}

Lincoln Creek Formation.-Large sea pen axes, usually in concretions, were found in rocks mapped (Pease and Hoover, 1957) as the Lincoln Creek Formation at University of Washington Burke Museum Invertebrate Paleontology (UWBM IP) loc. B9493, which is the eastern end of a roadcut, at about the level of the surface of the road, in almost structureless bioturbated tuffaceous siltstone. Bedding is indicated by lens-shaped, discontinuous accumulations of small shells, foraminifers, fish scales, and terrestrial plant

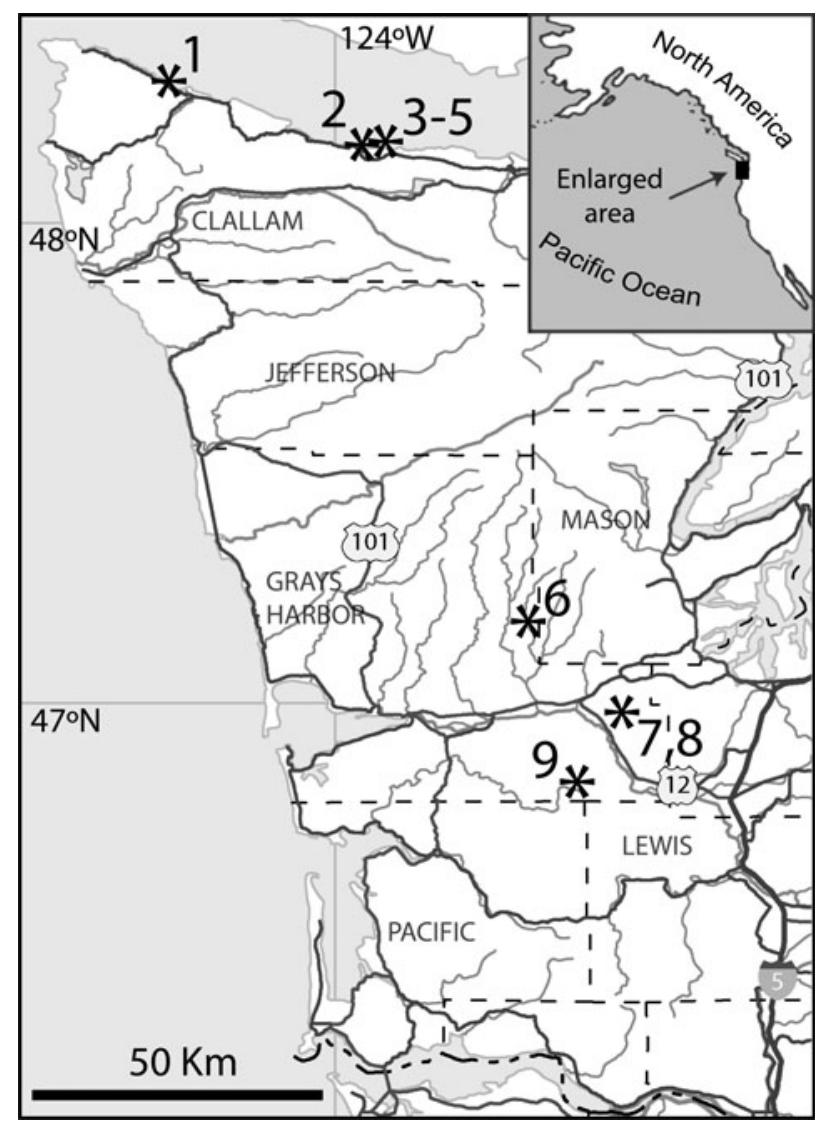

Figure 1. Localities for the studied octocorals in Washington State, USA: 1, UWBM IP B9497, near Sekiu River, Makah Formation, early Oligocene; 2, UWBM IP B9494, Pysht Formation, late Oligocene; 3-5, UWBM IP locs. B9490-92, between Murdock Creek and East Twin River, Pysht Formation, late? Oligocene; 6, Canyon River, Lincoln Creek Formation, Oligocene; 7, UWBM IP B9495, near Malone, Lincoln Creek Formation, late Eocene-early Oligocene; 8, UWBM IP B9496, east bank of Porter Creek, Lincoln Creek Formation, late Eocene-early Oligocene; 9, UWBM IP B9493, along Brooklyn-Oakville road, Lincoln Creek Formation, late Eocene-early Oligocene. detritus. A single piece of pumice $\sim 10 \mathrm{~mm}$ in diameter was found. Tubes that are lined with white quartz grains are up to $3 \mathrm{~mm}$ in diameter and more than $100 \mathrm{~mm}$ long, in some cases branching, and cut through the siltstone in no apparent preferred orientation. Mollusks in the siltstone include moderately large (up to $70 \mathrm{~mm}$ long) scaphopods and turrid, turritellid, naticid, and scaphandrid gastropods. Several fossil crabs were found, Pulalius vulgaris (Rathbun, 1926) being the most abundant; some were preserved in concretions, others were not. Bivalves are rare. One teleost otolith was found. The larger sea pen axis was in a concretion oriented nearly vertical with respect to bedding; smaller sea pen fragments were found in the organic accumulations in the siltstone and did not appear to have any preferred orientation. Large sea pen axes at this locality are nearly always vertically oriented and in concretions (LSG, personal observations).

A locality on Porter Creek (UWBM IP B9496) is in bioturbated tuffaceous siltstone that is exposed in the stream bed and bank. This locality has abundant, mostly vertically oriented carbonate 'pipes' similar to those described from some hydrocarbon seep deposits (e.g., Aiello, 2005), and the faunule includes gastropods, fragments of a limid bivalve and some thinshelled pectinids, scaphopods, and a few 'root tufts' of hexactinellid sponges. The crab Pulalius vulgaris is also present.

Near Malone, locality UWBM IP B9495, is a roadcut (originally along a logging railway) exposing tuffaceous siltstone. Mollusks found here include scaphopods, fasciolariid and ptychatractid gastropods, and the crab P. vulgaris.

The faunules at the Lincoln Creek Formation localities all correlate with the "Turritella-Priscofusus Zonule" of the Porter Bluffs section described by Armentrout et al. (1980), which is characterized by structureless, bioturbated fine-grained sediments with abundant gastropods and crabs, with few bivalves. The molluscan species from localities B9493, B9495, and B9496 are the same as those listed by Armentrout et al. (1980, figs. 20,21), which are most common in their Porter Bluff section, along the highway between Porter and Malone, between their localities PB6 to PB23. Armentrout et al. (1980) interpreted this zonule to represent bathyal to upper bathyal depths, with temperate to warm-temperate water temperatures. The Porter Bluff localities PB6 to PB23 are within the 'Echinophoria' fax Zone (Prothero et al., 2001a, fig. 6), late Eocene to earliest Oligocene in age (Global chrons C13r to $\mathrm{C} 12 \mathrm{n}, 30.5$ to 34.5 Ma; Prothero et al., 2001a).

Two fossils preserved in nodules were found as float on gravel bars of the Canyon River, on the south side of the Olympic Peninsula where a thick section of the Lincoln Creek Formation is exposed. Both nodules have the same siltstone lithology as others found in the uppermost part of the formation locally, deposited at depths of $\sim 200-600 \mathrm{~m}$, and possibly as deep as $760 \mathrm{~m}$, based on foraminiferans (Rau, 1966). Rau (1966) also concluded that water temperature was $2-10^{\circ} \mathrm{C}$. According to Prothero and Armentrout (1985), the age of the upper part of the Lincoln Creek Formation on Canyon River is late Oligocene. We cannot exclude the possibility that these fossil-bearing nodules may have come from farther upstream where older strata of the Lincoln Creek Formation are exposed, so late Oligocene is a minimum age for these fossils. 
Makah Formation.-A single loose, float concretion, on the beach terrace west of the mouth of the Sekiu River (UWBM IP B9497) contained the basal portion of two sea pen axes. The strata exposed are siltstone, mudstone, and turbidite layers deposited in a marine, deep-water paleoenvironment (Snavely et al., 1980). Fossils of all kinds are rare within the almost structureless mudstone and siltstone parts of the formation. Bedding is indicated by calcareous concretions, commonly containing glendonites, and in some cases mollusks (Squires and Goedert, 1994; Goedert, 1995), whale, fish, and wood falls (e.g., Goedert et al., 1995; Kiel and Goedert, 2006; Kiel et al., 2012), and cold-seep carbonate (Goedert and Campbell, 1995). Some glendonites in this part of the Makah Formation are in the same size range as the larger sea pen axes described herein, and sometimes mistaken for 'square bones' by fossil collectors. Some actual sea pen fossils have been referred to as square bones (e.g., some specimens from Australia: McCoy, 1877; Tate, 1877), however, glendonites are inorganic structures, and with close observation are easily differentiated from actual sea pen axes.

Pysht Formation.-Part of the Pysht Formation exposed along the coastline between the mouths of Murdock Creek westward to the mouth of East Twin River yielded 'gorgonian' holdfasts and an internode, as well as some minute sea pen axis fragments. The stratigraphically lowest strata studied herein (UWBM IP B9491) appear to be penecontemporaneously disturbed strata affected by undersea slumping or gravity flows. A large holdfast was found in these disturbed strata. Another holdfast and small internode section was found in a prominent, poorly sorted conglomerate composed of reworked concretions, molluscan shells and fragments, bone fragments (both cetacean and teleost), small shark teeth, some wood fragments (mostly bored by mollusks), and some igneous or metamorphic clasts (UWBM IP B9490). Stratigraphically above (and westward) is a sequence of mostly thin-bedded turbidite deposits with few molluscan fossils, but near the top of this section are some deposits (UWBM IP B9492) with more abundant molluscan shells, small brachiopods, wood fragments, terrestrial plant debris, a few shark teeth and fish otoliths, and small sea pen axis fragments. Stratigraphically higher are mudstones that at locality B9494 contain some concretions that apparently were exposed on the seafloor during Oligocene time, because one was found with a small 'gorgonian' holdfast and others have serpulid tubes attached to the concretion surface (JLG, personal observation).

The only extensive studies of mollusk fossils from this part of the Pysht Formation are by Durham (1944); Rau (1964) studied the foraminiferans. Magnetostratigraphic work by Prothero et al. (2001b) correlated the Pysht Formation to ca. 23.7-30.5 $\mathrm{Ma}$, late early Oligocene to latest Oligocene, whereas a detailed assessment by Nesbitt et al. (2010) concluded that most of the Pysht Formation is Oligocene, but it is not possible at this time to assign a more precise age.

\section{Materials and methods}

All illustrated specimens are deposited in the NRM PAL (Swedish Museum of Natural History, Stockholm, Department of
Palaeobiology); additional specimens and/or associated fossils are deposited in the UWBM (University of Washington, Burke Museum of Natural History and Culture). Bulk mudand siltstone samples $(\sim 3 \mathrm{~kg})$ from one locality in the lower part of the Pysht Formation (B9492) were dried and wetted several times to cause the rock to disaggregate for screening. Localities are described in the Appendix using section, township, and range, according to the USA Public Land Survey System; GPS coordinates are given using datum WGS84 (World Geodetic System). All macro-specimens were coated with ammonium chloride before photography, unless otherwise indicated. Small pennatulacean axes were mounted on aluminum stubs, coated with gold, and photographed with a Hitachi-4300 Scanning Electron Microscope (SEM).

Repositories and institutional abbreviations.-IGPS, Institute of Geology and Paleontology, Tohoku University, Sendai, Japan; NRM PAL, Swedish Museum of Natural History, Stockholm, Department of Palaeobiology; UWBM IP, University of Washington, Burke Museum of Natural History and Culture, Invertebrate Paleontology, Seattle, Washington, USA.

\section{Systematic paleontology}

Class Anthozoa Ehrenberg, 1834

Subclass Octocorallia Haeckel, 1866

Order Alcyonacea Lamouroux, 1816

Suborder Calcaxonia Grasshoff, 1999

Family Chrysogorgiidae Verrill, 1883

Genus Radicipes Stearns, 1883

Type species.—Radicipes pleurocristatus Stearns, 1883, by monotypy.

Radicipes? sp.

Figures 2, 3.1, 3.2

Occurrence.-Found as float derived from the Lincoln Creek Formation (probably the upper part), Canyon River, Grays Harbor County, Washington (precise locality details on file at NRM).

Description.-Straight axis fragments, slightly more than $1 \mathrm{~mm}$ diameter, and up to at least $160 \mathrm{~mm}$ long, circular in cross section, composed of thin, papery concentric layers, iridescent, with translucent rhizoidal base, 'roots' that appear to become spatulate distally.

Materials._Axis with rhizoidal base, NRM PAL Cn 75267; axis without base, NRM PAL Cn 75266; both preserved in nodules.

Remarks.-Species of Chyrsogorgiidae are widespread in the world's oceans and live at depths of 31-4492 m (Pante and Watling, 2011; Pante et al., 2012). Being straight fragments without indication of spiraling or branching and possessing a rootlike base, the fossils from the Lincoln Creek Formation closely resemble unbranched, whip-like chrysogorgiid taxa. 

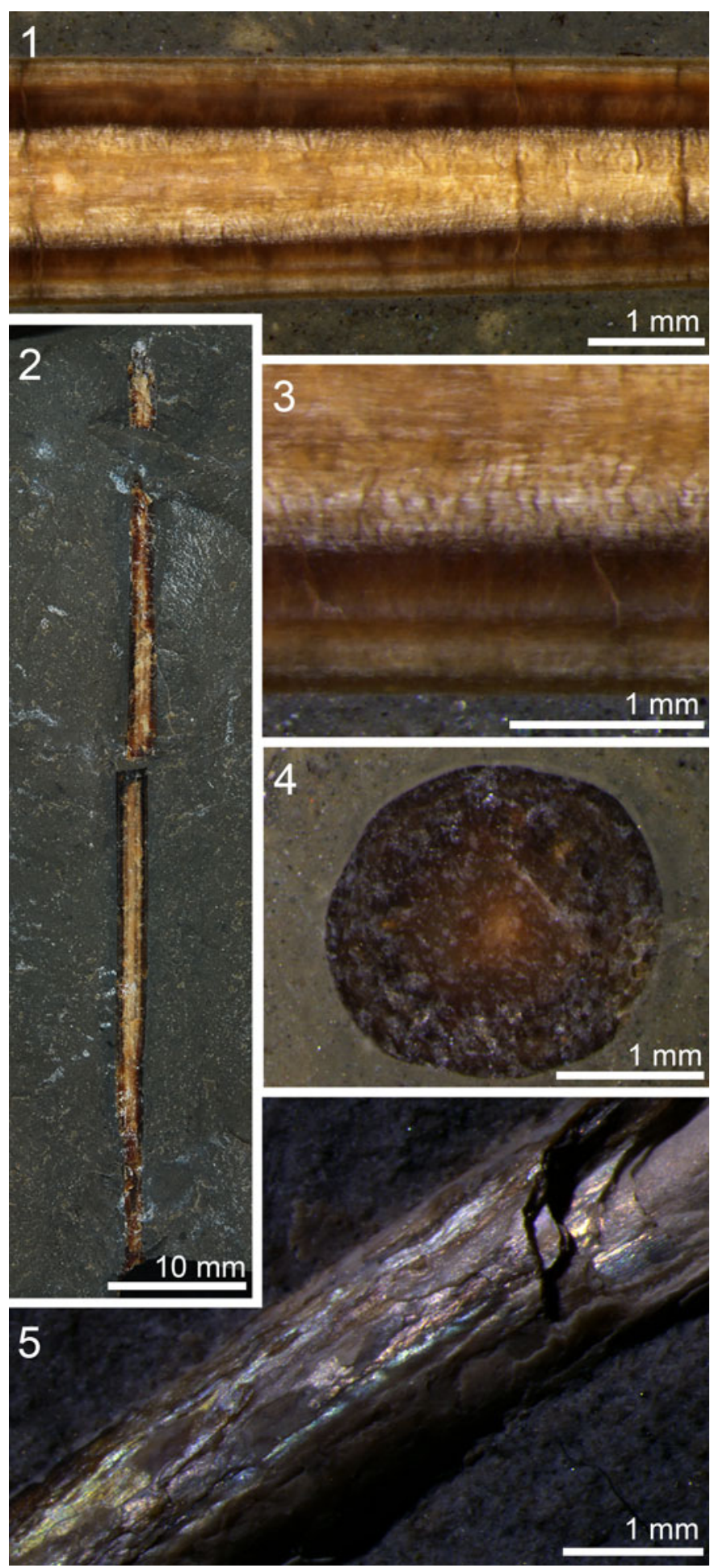

Figure 2. The Oligocene chrysogorgiid Radicipes? sp. from the Lincoln Creek Formation, Canyon River, Grays Harbor County, Washington; specimens not whitened. (1-4) Longitudinal and cross sections of the longer axis without holdfast (NRM PAL Cn 75266), (5) close-up detail of axis with holdfast showing iridescence and laminar structure (NRM PAL Cn 75267).

One genus, Radicipes, has species that live on continental slopes and seamounts in all the world's oceans, including the North Pacific, at depths of $241-3500 \mathrm{~m}$, on soft sediments, and individual colonies have rootlike bases and are up to $1 \mathrm{~m}$ long (Stearns, 1883; Cordeiro et al., 2017, and references therein).
For example, Radicipes sakhalinensis Dautova, 2018, found living at depths exceeding $3000 \mathrm{~m}$ in the Sea of Okhotsk, has a very similar rootlike base (Dautova, 2018, figs. 1G-I), as does R. pleurocristatus (Stearns, 1883, fig. 1); species of other unbranched genera have disk-like calcified bases, or have an axis that is not circular in cross section (e.g., Cairns and Cordeiro, 2017). Some species of Chrysogorgia Duchassaing and Michelotti, 1864, also have rhizoidal bases (e.g., Cairns, 2001), but colonies branch and are generally of a much smaller size overall, in many cases smaller in length than the largest fossil axis fragment described herein. Unfortunately, we were unable to find any sclerites preserved, nor is there any indication of polyp arrangement.

The largest fossil axis, NRM PAL Cn 75266, is in a nodule that broke into several pieces and exposed a longitudinal section of the axis for $\sim 70 \mathrm{~mm}$. The axis has a slightly oblique transverse fracture that occurred before lithification of the nodule, demonstrating that the axis was originally brittle, as has been noted by Cordeiro et al. (2017) for species of Radicipes. The paleoenvironmental setting represented by the upper Lincoln Creek Formation in the Canyon River section would have been cold, deep water (up to $600 \mathrm{~m}$ ), with a soft, muddy bottom, typical of that inhabited by Recent species of Radicipes (Cordeiro et al., 2017). We cannot exclude the possibility that the Lincoln Creek Formation specimens represent an early stage, before branching, of some extremely large species of Chrysogorgia. Also, because of the fragmentary nature of the fossils, we have questioned the generic identity and it should be regarded as provisional; however, regardless of genus, these fossils are the first known for the family Chrysogorgiidae.

Family Isididae Lamouroux, 1812

Subfamily Keratoisidinae Gray, 1870

Genus Isidella Gray, 1858

Type species.—Isis elongata Esper, 1788, by monotypy.

Remarks.-See Ott (1989, 1995), Grasshoff and Scheer (1991), and Yang et al. (2014) for discussion and clarification of publication dates of some taxa described by Esper (17881830), including how and why his plates were not necessarily published at the same time as the corresponding descriptions. Bayer (1990) provided a detailed discussion as to the validity of genus Isidella.

Isidella $\mathrm{sp}$.

Figure 3.3-3.7

Occurrence.-Lower part of the Pysht Formation, Clallam County, Washington (UWBM IP locs. B9490 and B9491). Late Oligocene.

Description.-The largest holdfast, NRM PAL Cn 75257 (Fig. 3.7), is $56.3 \mathrm{~mm}$ long, $35 \mathrm{~mm}$ wide, and up to $2 \mathrm{~mm}$ thick, with broadly scalloped edges, and a surface with numerous radiating grooves. The underside is not visible. Another holdfast, NRM PAL Cn 75259 (Fig. 3.3-3.5), is 38 $\mathrm{mm}$ high, ovoid to round in cross-section at the end of the basal stalk, $11 \mathrm{~mm}$ in diameter; the wider end is $42.8 \times 29.5$ 


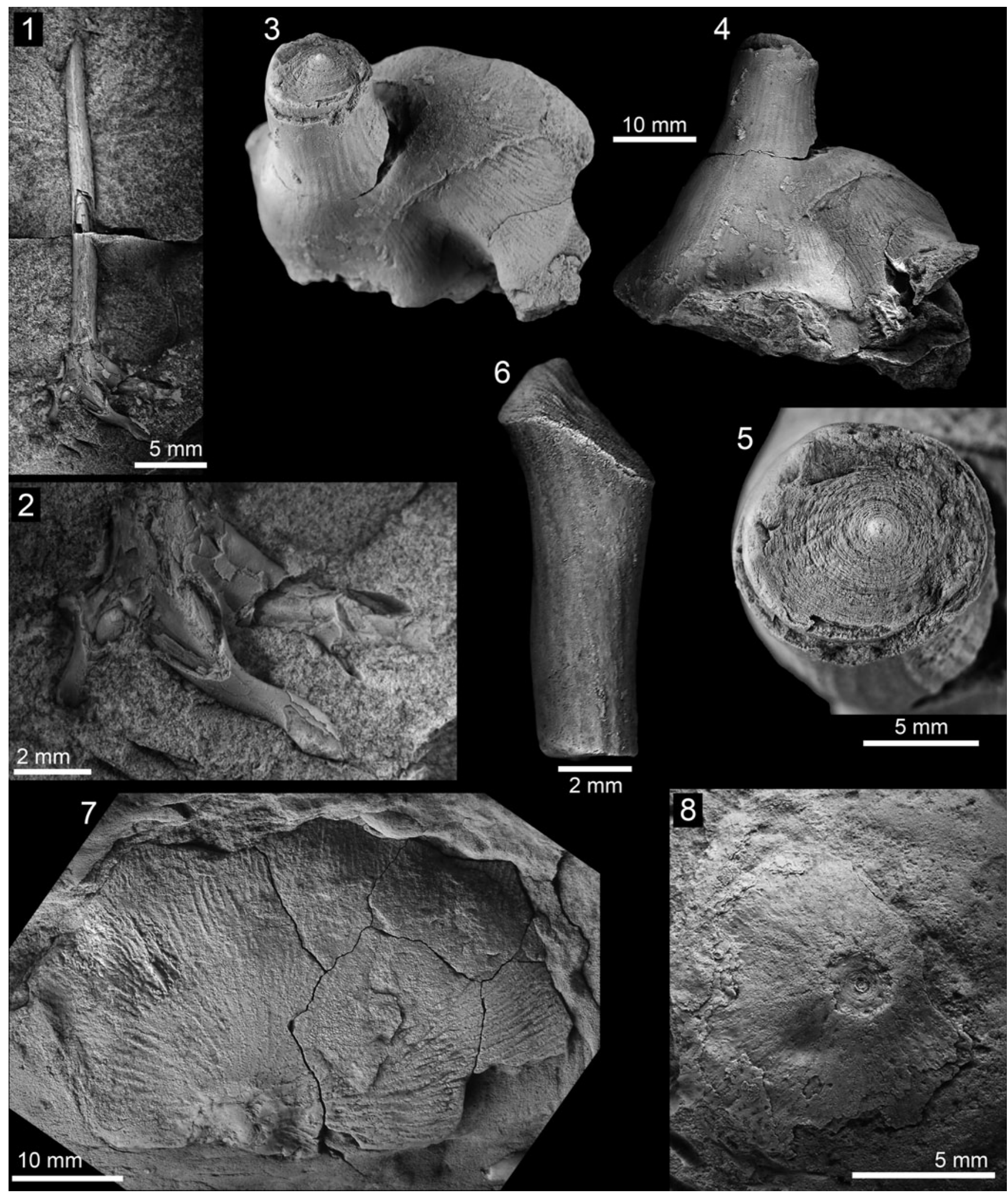

Figure 3. Octocorals (Calcaxonia) from Eocene-Oligocene deposits in western Washington, USA. (1, 2) The chrysogorgiid Radicipes? sp., axis with holdfast (NRM PAL Cn 75267), Lincoln Creek Formation, Canyon River, Grays Harbor County, Washington. (3-7) The isidid Isidella sp. from the lower part of the Pysht Formation, west of Murdock Creek, Clallam County, Washington; (3-5) holdfast showing fine radial striations and stalk with condyle with central point (NRM PAL Cn 75259); (6) small, solid internode with faint, widely spaced longitudinal striations (NRM PAL Cn 75277); (7) large holdfast with scalloped margin and numerous radiating grooves on surface (NRM PAL Cn 75257). (8) Holdfast of an unidentified octocoral (NRM PAL Cn 75258). 


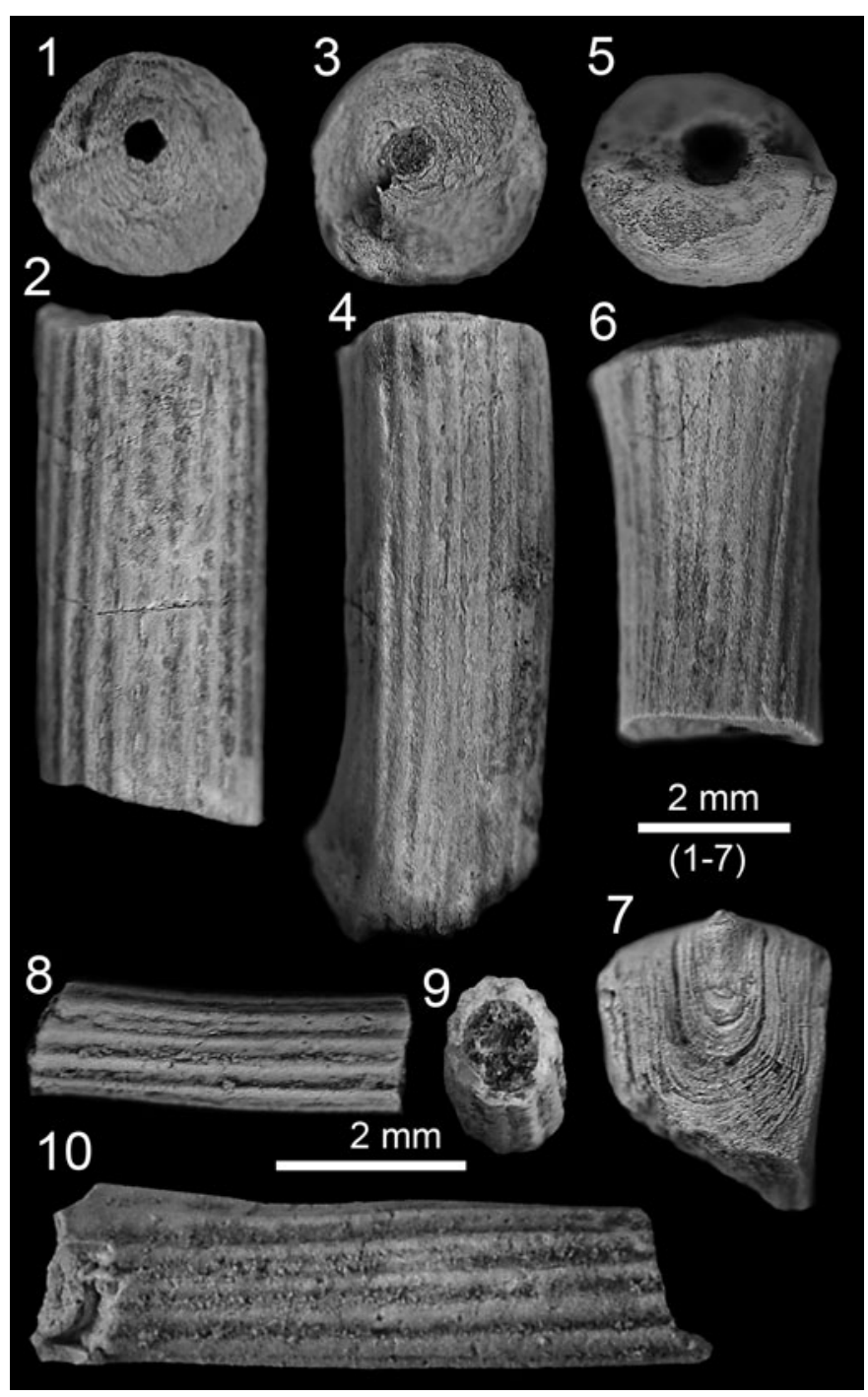

Figure 4. The isidid Lepidisis? sp., Oligocene, lower part of the Pysht Formation, west of Murdock Creek, Clallam County, Washington, USA. (1-6) Fragmented internodes with narrow canal (NRM PAL Cn 75269); (7) specimen with oblique end, showing concentric growth rings and a sediment-filled central canal (NRM PAL Cn 75270); (8-10) two fragments of a small, hollow internode (NRM PAL Cn 75271); apical view (9) showing hollow interior (specimen not whitened)

$\mathrm{mm}$. The central shaft is smooth externally, with striations faintly visible, with numerous concentric layers and condyle with a central point. The base has an uneven edge, and a dorsal surface with numerous radiating shallow grooves. The underside is not visible. A small internode (NRM PAL Cn 75277; Fig. 3.6) appears to have been a lateral branch, smooth externally with faint striations and is $11 \mathrm{~mm}$ long, solid, slightly flattened so that it is ovoid in cross-section with concentric rings, $3.4 \times 5.2 \mathrm{~mm}$ diameter at its larger end, with a distinct condyle with a broad point located off center, 2.8 mm diameter at its smaller end.

Materials.—Large holdfast, NRM PAL Cn 75257 from UWBM IP loc. B9491; smaller holdfast with stalk, NRM PAL Cn 75259, and small internode, NRM PAL Cn 75277, both from UWBM IP loc. B9490.
Remarks.-Because Gray (1858) did not properly define his new genus Isidella, Verrill (1883) expressed doubt about its validity. Etnoyer (2008) provided a discussion of the problems with the taxonomy of Isidella, and followed Bayer (1990) who accepted the genus as valid. The fossils from the Pysht Formation offer little in the way of diagnostic characters other than the nature of the calcareous holdfasts, the calcareous internode demonstrating that branching was from a horny node, as well as the slightly flattened cross-section of the small internode that may indicate that the colony branched in one plane instead of a bush-like growth pattern. This best fits the genus Isidella. With few fossils to examine, unequivocal assignment to genus is impossible at this time because other genera of Keratoisidinae also branch from the nodes or internodes, or have internodes that are in some cases hollow and/or fluted (e.g., Bayer, 1981; Bayer and Stefani, 1987; Alderslade and McFadden, 2012; Duenas et al., 2014). Another genus within the Keratoisidinae, Acanella Gray, 1870, also branches from the nodes, and is similar to Isidella, but differs in branching pattern; whether pattern of branching is a stable character that can be used to differentiate genera within the Keratoisidinae is doubtful (e.g., Verrill, 1883; France, 2007; Duenas et al., 2014). Assignment of the fossils from the Pysht Formation to Isidella is somewhat provisional, but Isidella lives and is common in deep parts of the North Pacific Ocean, forms large individual colonies, and can form dense thickets (Etnoyer, 2008; Andrews et al., 2009; Serrato Marks et al., 2017).

\section{Genus Lepidisis Verrill, 1883}

Type species.—Lepidisis caryophyllia Verrill, 1883, by subsequent designation (Kükenthal, 1915, p. 119).

\section{Lepidisis? sp.}

Figure 4

Occurrence.-Lower part of the Pysht Formation, Clallam County, Washington (UWBM IP loc. B9492). Late Oligocene.

Materials.—Internode fragments, NRM PAL Cn 75269-75271.

Remarks._All available specimens are only sections of relatively long and delicate internodes. The largest, $\sim 32 \mathrm{~mm}$ long and $4 \mathrm{~mm}$ in diameter, was originally longer, but is eroded at both ends. It has a small central canal throughout that is $\sim 0.5 \mathrm{~mm}$ across. The other two specimens are hollow; the larger specimen is $8.4 \mathrm{~mm}$ long and $\sim 2 \mathrm{~mm}$ in diameter, with a central canal $\sim 1 \mathrm{~mm}$ across; the smaller is $\sim 7 \mathrm{~mm}$ long and $1 \mathrm{~mm}$ diameter. Other than conspicuous fluting that appears to slightly twist along its length, the surface is smooth. Fossils such as these could be overlooked because of their superficial similarity to parts of some scaphopod shells, particularly those with longitudinal sculpture and a large-diameter central canal. A few scaphopod fragments were found at the same locality, however, because their sculpture does not twist along their length, and being aragonitic with a three-layer structure (Bøggild, 1930; Smith and Spencer, 2016), they are easy to differentiate from Lepidisis? sp. internodes. 


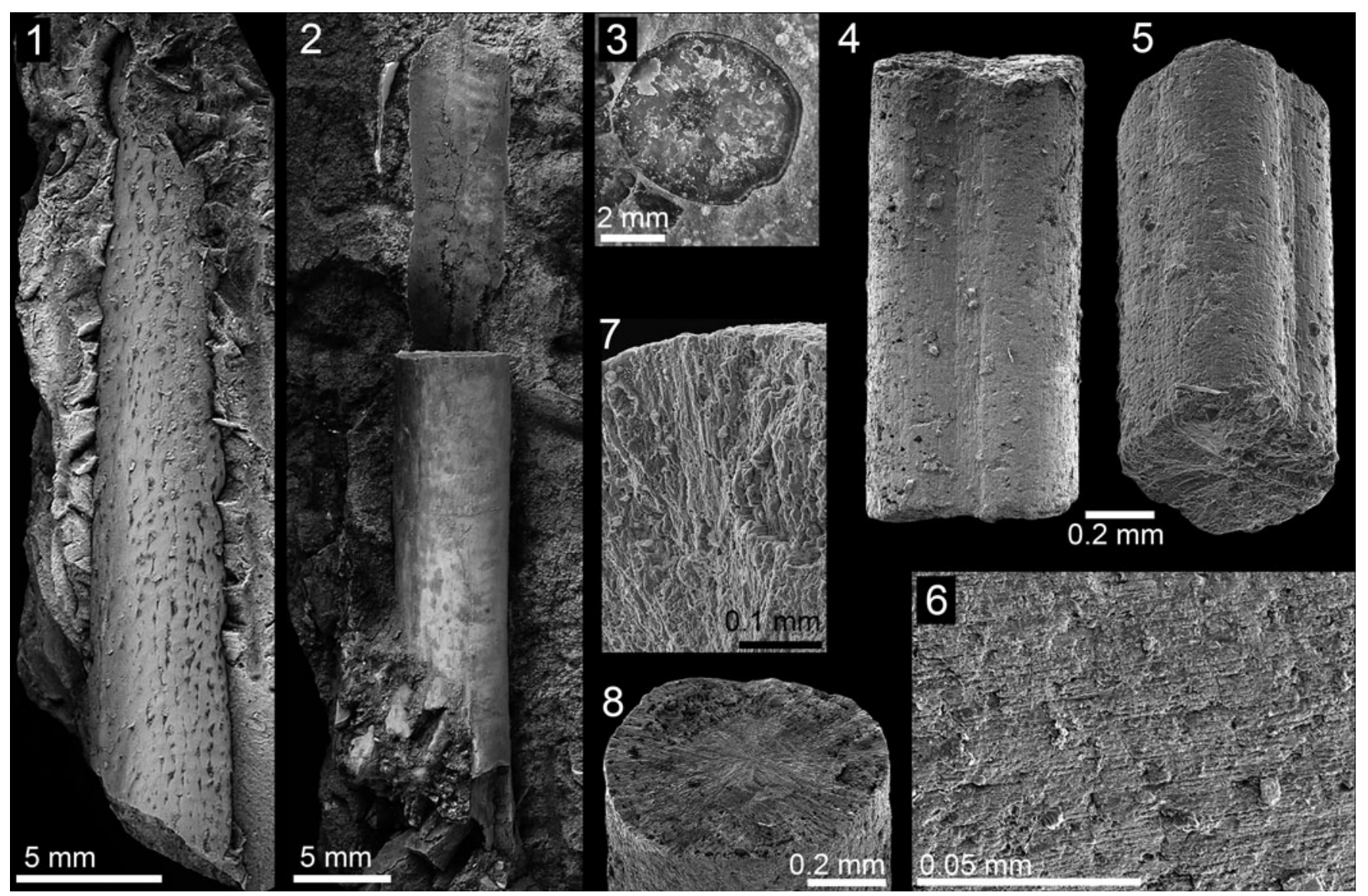

Figure 5. Pennatulacean octocorals from late Eocene-Oligocene strata in western Washington State. (1-3) 'Graphularia' (?) aff. sasai Yabe, 1955: (1) axis with pitted surface (NRM PAL Cn 75260), early Oligocene, Makah Formation, Sekiu River, Clallam County; (2) nearly smooth axis, crushed on lower end (NRM PAL Cn 75264), late Eocene or early Oligocene, Lincoln Creek Formation, Brooklyn-Oakville road, Grays Harbor County; (3) same specimen as in (1), showing nearly circular cross section with shallow longitudinal groove in lower right (polished surface, not whitened). (4-8) 'Graphularia' sp. represented by small, axial fragments, Oligocene, lower part of the Pysht Formation, west of Murdock Creek, Clallam County: (4-6) specimen with quadrate or rounded-rectangular cross section (NRM PAL Cn 75276); (6) close-up on finely striated surface structure; $(\mathbf{7 , 8})$ specimen with nearly circular cross section and a radial internal arrangement of crystals (NRM PAL Cn 75280).

These internodes with a smooth surface, fluted longitudinally, being hollow and showing no indication of any branching, best fit the diagnostic characters for species of Lepidisis. Only 11 or 12 species of Lepidisis are known, none as fossils, so the specimens from the Pysht Formation, if correctly identified, are the first fossil record for the genus. Species of Keratoisis Wright, 1869, also have hollow internodes, but colonies tend to be more robust and with branches. However, as already noted, whether colonies branch or not is no longer regarded as a reliable character for differentiating genera within the Keratoisidinae.

\section{Octocorallia indet.}

Figure 3.8

Occurrence.-Pysht Formation, Clallam County, Washington; UWBM IP loc. B9494. Late Oligocene.

Materials.-One holdfast attached to a small concretion, NRM PAL Cn 75258, collected by Terry Iversen.

Remarks.-This small holdfast is $\sim 10 \mathrm{~mm}$ across, the 'stem' was central, with the surface displaying faint radiating grooves. It is attached to the outer surface of a small nodule that is $\sim 70 \mathrm{~mm}$ long $\times 50 \mathrm{~mm}$ wide, containing a small glendonite. Light-colored, roughly circular places on the nodule may indicate other areas where holdfasts were once located. Similar small fossil holdfasts have been described from Eocene and Oligocene strata in the southeastern United States (e.g., Giammona and Stanton, 1980; Kocurko, 1988, 1993; Kocurko and Kocurko, 1992, and references therein), some even attached to mudstone nodules, but most of these appear smooth and do not seem to have the faint grooves possessed by the Pysht Formation specimen. Similar small fossil holdfasts were reported from Paleocene deposits in Denmark (Nielsen, 1917) and Eocene rocks on Seymour Island, Antarctica (Stolarski, 1996).

\section{Order Pennatulacea Verrill, 1866}

Remarks.-Pennatulacea, originally as a suborder, is most often attributed to Verrill in 1865, but the publication date of Volume 4 of the Proceedings, and the associated Communications of the Essex Institute (for 1864-1865) is clearly given on the cover as 1866. The title page of Verrill's (1866) article states 
"communicated February 29, 1865," but apparently the actual year of publication should be cited as 1866 (see Williams, 1999, for additional comments and references).

Suborder and Family uncertain

Genus Graphularia Milne-Edwards and Haime, 1850

Type species.-Graphularia wetherelli Milne-Edwards and Haime, 1850, by monotypy; Eocene, London Clay, United Kingdom.

Remarks.-See Bałuk and Pisera (1984) and Reich and Kutscher (2011) for discussion of the genus Graphularia and reasons why it is considered tentative.

'Graphularia' (?) aff. sasai Yabe, 1955

Figure 5.1-5.3

Diagnosis._Yabe's (1955, p. 288) diagnosis of 'G.' (?) sasai states "...long, straight, and cylindrical, very slightly taper from one end to the other, and are circular in cross-section."

Occurrence.-Holotype of 'G.' (?) sasai, IGPS No. 66353, from Hokkaido, Japan; Charo Formation (=Tyaro Formation of Yabe, 1955), possibly also Poronai Formation (Sato [1972], citing Shimokawara [1963], but this is not in Sato's list of references). 'Graphularia' (?) aff. sasai, Washington State, USA; Lincoln Creek Formation (UWBM IP loc. B9493) and Makah Formation (UWBM IP loc. B9497). Early Oligocene in Hokkaido, late Eocene to early Oligocene in Washington State.

Description.-The large specimens from the Lincoln Creek Formation are, in most cases, preserved in life position, vertical with respect to bedding, are brown to black in color, incomplete, but as preserved they can exceed $300 \mathrm{~mm}$ in length and are up to $8 \mathrm{~mm}$ in diameter. They are generally circular in cross-section, with very slight depressions visible on two sides toward the upper ends. The lower, basal parts appear to end in a blunt point, as shown in the Makah Formation specimens (Fig. 5.1). The lower ends display a roughened surface due to imprints of chimney cells. The surface of the upper parts of the rods are smoother, but still have a distinct grain almost resembling a smooth piece of wood. In cross-section, annular rings are distinctly visible along with radial fibrous structure. Smaller fragments were found in the sediments surrounding the larger rods at locality B9493; these are described under 'Graphularia' spp. because we are uncertain as to whether these represent the same species as the larger specimens.

Materials.-NRM PAL Cn 75260, two axial rods in one concretion from UWBM IP loc. B9497; NRM PAL Cn 75262-75264 (all parts of one individual), and 75265, large axial rods in nodules and siltstone from UWBM IP loc. B9493.

Remarks._'Graphularia' (?) sasai was described based on fragments of large pennatulacean axes collected from the late Eocene to early Oligocene Tyaro Formation (Onbetu = Ombetsu Group) in Japan. These strata are today called the
Charo Formation and are of early Oligocene age (e.g., Kurita, 2004). According to Yabe (1955, p. 291), the ' $G$.' (?) sasai specimens were preserved in sections of somewhat cylindrical concretions and apparently in life position, vertical with respect to bedding. Their large size (sections broken at each end, but up to $250 \mathrm{~mm}$ long and $11 \mathrm{~mm}$ diameter), geochronological age, and preservation mode closely match those of the largest specimens from the Lincoln Creek Formation. The cross-sections and surface texture of the specimens from Japan described by Yabe (1955) are similar to those of the Lincoln Creek Formation specimens, at least in part. The specimens from Japan (Yabe, 1955, fig. 1) and Washington (Fig. 5.2, 5.3) are circular in cross-section and appear relatively smooth. Yabe (1955, p. 288-289) described the surface of the specimens from Japan as having "very fine longitudinal corrugations," but his illustration (Yabe, 1955, fig. 2) does not have a scale, and the caption only indicated "greatly enlarged." The fossil from the Makah Formation (Fig. 5.1) shows a roughened surface similar in appearance to the enlarged illustration of ' $G$.' (?) sasai, but we are unable to make direct comparisons at this time. Because the fossils from Japan and Washington are incomplete, we cannot exclude the possibility that they all represent different parts of the axis from the same or a closely related species. Living pennatulacean species are known to be widely distributed even across oceanic basins (e.g., Williams, 2011) so it would not be surprising to find the same species inhabiting both sides of the North Pacific Ocean during Paleogene time. 'Graphularia' (?) sasai was also listed by Sato (1972, table 1), citing Shimokawara (1963) as the source of the record, from the late Eocene Poronai Formation on Hokkaido, but these specimens were not described, and it is not clear whether these were the same specimens described by Yabe (J. Nemoto, IGPS, personal communication, 2021).

Large pennatulacean axes have been described from Cenozoic strata of Australia and New Zealand. One species, 'Graphularia' senescens Tate, 1877, originally considered to be a belemnite, is synonymous with 'Graphularia' robinae McCoy, 1877, from southern Australia, and apparently abundant, according to McCoy (1877), in some sections of the late Oligocene Jan Juc Marl near Waurn Ponds near Geelong, and a place called 'Bird Rock Bluff.' Both species were from the same Waurn Ponds locality, with 'G.' senescens being published in February 1877, and 'G.' robinae in September 1877; we consider them to be the same species. Although 'G.' senescens is similar in size (length more than $300 \mathrm{~mm}$, diameter up to $12 \mathrm{~mm}$; McCoy, 1877) to ' $G$.' (?) sasai from Japan and 'G.' (?) aff. sasai from Washington State, 'G.' senescens becomes distinctly quadrangular in the assumed upper portions, described as "square bones" by quarrymen (McCoy, 1877; Tate, 1877). No mention was made as to whether the Australian specimens were preserved in life position. From several different localities in late Eocene to early Miocene strata in New Zealand, large pennatulacean axes named 'Graphularia' longissima Squires, 1958, were described as circular in cross-section in the lower (= basal) portion, being subquadrangular in the upper part, and up to at least $300 \mathrm{~mm}$ long and $13 \mathrm{~mm}$ in diameter. The pattern of pits on the more basal part of ' $G$.' longissima (Squires, 1958, pl. 2, fig. 15) is similar to 'G.' (?) aff. sasai from the 
Makah Formation (Fig. 5.1, 5.3); no mention was made as to whether ' $G$.' longissima was preserved in life position.

Larger sea pen axes, such as 'G.' (?) sasai from Japan and 'G.' (?) aff. sasai from Washington, have good potential for preservation in life position, at least for the basal part of the axis. Some sea pens have axial rods up to $2 \mathrm{~m}$ long, with up to one-fourth of that length embedded in the sediment already (e.g., Greathead et al., 2007). In some species, the basal portion of the axis is also more heavily calcified as well (de Moura Neves et al., 2018), which would presumably also enhance their preservation potential. We suspect that these fossil axes may be relatively common in Cenozoic strata in western Washington, but have been overlooked and assumed to be burrows, plant stems, or inorganic structures (i.e., glendonites). Over a period of 30 years, $\sim 30$ specimens of ' $G$.' (?) aff. sasai have been collected from locality B9493; most were discarded because they were assumed to be burrows and others lost to personal collections, with all but one oriented vertically with respect to bedding (LSG, personal observation).

\section{'Graphularia' spp.}

Figure 5.4-5.8

Occurrence.-Western Washington State, USA; lower part of the Lincoln Creek Formation in Grays Harbor County (UWBM IP locs. B9493-B9496); Pysht Formation, Clallam County (UWBM IP locs. B9490 and B9492). Late Eocene to Oligocene.

Materials.-Lincoln Creek Formation: NRM PAL Cn 75273, fragments with circular cross-section, UWBM IP loc. B9496; NRM PAL Cn 75274, three fragments from UWBM IP loc. B9495; NRM PAL Cn 75275, several fragments from UWBM IP loc. B9493. Pysht Formation: NRM PAL Cn 75272 (lot of 6 fragments), NRM PAL Cn 75276 (quadrate fragment, Fig. 5.4-5.6), NRM PAL Cn 75280 (fragment with circular cross-section, Fig. 5.7, 5.8), UWBM 115703 (one rod fragment, quadrate in cross-section), UWBM 115704-115708 (five rod fragments, circular in cross-section), all from UWBM loc. B9492; NRM PAL Cn 75281, rod fragment in coarse matrix, UWBM IP loc. B9490.

Remarks.-Associated with large specimens identified as ' $G$.' (?) aff. sasai at locality B9493 were fragments of small sea pen axes up to $2.5 \mathrm{~mm}$ in diameter, and $>5 \mathrm{~mm}$ long, chalky and white in color. These have no distinguishing characters, other than being circular in cross-section and composed of layers of radial calcite. Small fragments were also found in the lower part of the Lincoln Creek Formation on Porter Creek (loc. B9496), and near Malone, Washington (loc. B9495). Because these are all from the same part of the Lincoln Creek Formation and all are circular in cross-section, it is possible that they are fragments of juvenile ' $G$.' (?) aff. sasai, but we cannot be certain at this time.

On the north side of the Olympic Peninsula, locality B9492, in the Pysht Formation in Clallam County west of Murdock Creek, produced 24 specimens, all small fragments $<10 \mathrm{~mm}$ long and $<2 \mathrm{~mm}$ in diameter. These differ from the Lincoln Creek Formation specimens in that while some are circular in cross-section, others are slightly flattened or distinctly quadrate. A few of the smaller quadrate fragments have a central groove on each flat side. Even though fossils of sea urchin spines of similar size to the sea pen axis fragments are found together at this locality, it is easy to differentiate them; urchin spines are composed of minutely porous stereom, whereas the sea pen axes are solid, composed of annular layers of calcite, which in cross section appears similar to rings of a tree along with radial calcite. One specimen (NRM PAL Cn 75281, from locality B9490) is a rod, circular in cross-section, $17.5 \mathrm{~mm}$ long (missing $\sim 2 \mathrm{~mm}$ near one end) and $1.8 \mathrm{~mm}$ in diameter, preserved in coarse matrix with a small shark tooth and bivalve fragments. Fossils of small sea pen axes such as these from elsewhere in the world are placed in various species within the genus ' $\mathrm{Gra}$ phularia' (e.g., Branco, 1885; Nielsen, 1917; Yabe and Sugiyama, 1937; Shapiro and Ramsdell, 1965; Bałuk and Pisera, 1984; Mel'nikov et al., 2006; Reich and Kutscher, 2011). The Pysht Formation specimens are not complete enough to assign to species, but they do indicate that there is some previously unrecognized pennatulacean diversity preserved within these strata.

\section{Discussion}

Alcyonacea. - The specimens of Isidella sp. and Lepidisis? sp. of the Isididae, and Radicipes? sp. of the Chrysogorgiidae reported here are the first confirmed fossils of the Alcyonacea from north of California in western North America. Estimated divergence times among Cnidaria using a time-calibrated molecular phylogeny (Park et al., 2012) indicate that the Isididae diverged from other Alcyonacea at the base of the Jurassic, with error margins ranging from the Carboniferous to the early Cretaceous. Fossil calibration points for the Park et al. (2012) time tree were the splits between three pairs of genera of scleractinian corals, based on data from Veron et al. (1996), and did not include any fossil Octocorallia. In the time-calibrated molecular tree of the Anthozoa, Quattrini et al. (2020) and McFadden et al. (2021) pushed the split of the calcaxonian families Isididae and Chrysogorgiidae even further back in time, to the early Triassic. The fossil calibration points for these trees included an early Miocene record of Keratoisis internodes from New Zealand (Hayward, 1977). These estimated early origins of Isididae and Chrysogorgiidae are at odds with the fossil record, with the first holdfasts and corallia assignable to the Isididae appearing in the Late Cretaceous (Voigt, 1958; Małecki, 1982; Zítt and Nekvasilová, 1993; Schlagintweit and Gawlick, 2009; Borszcz et al., 2013; Löser, 2015), and the Oligocene record of Chrysogorgiidae reported here.

Pennatulacea.-Frond-like fossils as old as the Ediacaran had been attributed to the Pennatulacea (Glaessner and Wade, 1966; Jenkins, 1985; Waggoner and Collins, 2004), although more recent re-analyses of their morphologies questioned these interpretations (Antcliffe and Brasier, 2007, 2008). Quattrini et al. (2020) used a time-calibrated molecular phylogeny to date the split of Pennatulacea from the remaining Calcaxonia-Pennatulacea clade to the Late Devonian, and suggested an origin of their high-Mg calcite 
axes in the early Paleozoic calcite seas. The fossil record of high-Mg calcite axes of the crown Pennatulacea, however, only reaches back to the Late Cretaceous (Voigt, 1958; Antcliffe and Brasier, 2008; Reich and Kutscher, 2011). This is notably younger than the molecular age estimates. The fossils to calibrate the dates in the phylogeny of Quattrini et al. (2020) did not include any Pennatulacea; the only calibration point among the entire Octocorallia was an early Miocene record (Hayward, 1977) of the isidid Keratoisis from New Zealand.

Another time-calibrated molecular phylogeny, with focus on Pennatulacea and using the early to middle Eocene record of Virgularia presbytes Bayer, 1955, from the Pointe-a-Pierre Formation in Trinidad as a calibration point, indicates an Early Cretaceous origin of the Pennatulacea (García-Cárdenas et al., 2020). However, the Eocene record of $V$. presbytes has been shown to be a trace fossil instead of an octocoral (Häntzschel, 1958). Despite this invalid calibration point, the suggested Early Cretaceous origin of the Pennatulacea is in much better agreement with the fossil record than the early Paleozoic origin indicated by Quattrini et al. (2020) and McFadden et al. (2021) and is consistent with an origin of pennatulacean high-Mg calcite axes within a time of calcite seas (Balthasar and Cusack, 2015).

Although fossil pennatulacean axes are relatively common in Europe, the only Cenozoic fossils previously reported from the North Pacific basin are from Japan (Yabe and Sugiyama, 1937; Yabe, 1955). The late Eocene to Oligocene specimens of 'Graphularia' (?) aff. sasai and 'Graphularia' spp. from Washington State are the first fossil records from the eastern North Pacific and extend the geographic range of 'Graphularia' considerably.

\section{Acknowledgments}

This project would not have happened without the help of R. Boessenecker (College of Charleston, South Carolina) in the earliest stages of this project. We thank R. Eng (UWBM) for providing locality and specimen numbers. The small holdfast from the Pysht Formation was collected and donated by T. Iversen (Bremerton, Washington). S.V. Goedert participated in fieldwork in the Canyon River area. Information regarding the age and geological formation for ' $G$.' (?) sasai from Hokkaido was provided by K. Takahashi (Geological Survey of Japan). We are grateful to J. Nemoto (IGPS) for additional information about ' $G$.' (?) sasai, as well as providing a difficult to find reference. Permission to access localities on timberlands owned by Green Diamond Resources was arranged by M. Golliet (Shelton, Washington office). We are indebted to M. Reich (Bayerische Staatssamlung für Paläontologie und Geologie, Munich, Germany), an anonymous reviewer, and E. Currano and R. Elias (editors) for their comments and guidance, which greatly improved this paper. Copies of some hard to find literature were kindly provided by M. Reich.

\section{References}

Aiello, I.W., 2005, Fossil seep structures of the Monterey Bay region and tectonic/structural controls on fluid flow in an active transform margin: Palaeogeography, Palaeoclimatology, Palaeoecology, v. 227, p. 124-142.
Alderslade, P., and McFadden, C.S., 2012, A new genus and species of the family Isididae (Coelenterata: Octocorallia) from a CMAR biodiversity study, and a discussion on the subfamilial placement of some nominal isidid genera: Zootaxa, v. 3154, p. 21-39.

Andrews, A.H., Stone, R.P., Lundstrom, C.C., and Vogelaere, A.P. De, 2009, Growth rate and age determination of bamboo corals from the northeastern Pacific Ocean using refined ${ }^{210} \mathrm{~Pb}$ dating: Marine Ecology Progress Series, v. 397, p. 173-185.

Antcliffe, J.B., and Brasier, M.D., 2007, Charnia and sea pens are poles apart: Journal of the Geological Society, London, v. 164, p. 49-51.

Antcliffe, J.B., and Brasier, M.D., 2008, Charnia at 50: developmental models for Ediacaran fronds: Palaeontology, v. 51, p. 11-26.

Armentrout, J.M., 1974, Molluscan Paleontology and Biostratigraphy of the Lincoln Creek Formation (Late Eocene-Oligocene), Southwestern Washington [Ph.D. dissertation]: Seattle, University of Washington, $479 \mathrm{p}$.

Armentrout, J.M., McDougall, K., Jefferis, P.T., and Nesbitt, E., 1980, Geologic field trip guide for the Cenozoic stratigraphy and late Eocene paleoecology of southwestern Washington, in Oles, K.F., Johnson, J.G., Niem, A.R., and Niem, W.A., eds., Geologic Field Trips in Western Oregon and Southwestern Washington: State of Oregon, Department of Geology and Mineral Industries Bulletin 101, p. 79-119.

Aurivillius, M., 1931, The gorgonarians from Dr. Sixten Brock's expedition to Japan and Bonin islands in 1914: Kungliga Svenska Vetenskapsakademiens Handlingar, Tredje Serien, v. 9, p. 1-337.

Balthasar, U., and Cusack, M., 2015, Aragonite-calcite seas-Quantifying the gray area: Geology, v. 43, p. 99-102.

Bałuk, W., and Pisera, A., 1984, A new species of sea pens, Graphularia transaedina sp. n., from the Korytnica Clays (Middle Miocene; Holy Cross Mountains, central Poland): Acta Geologica Polonica, v. 34, p. 203-211.

Bayer, F.M., 1955, Remarkably preserved fossil sea-pens and their Recent counterparts: Journal of the Washington Academy of Sciences, v. 45, p. 294-300.

Bayer, F.M., 1981, Key to genera of Octocorallia exclusive of Pennatulacea (Coelenterata: Anthozoa), with diagnoses of new taxa: Proceedings of the Biological Society of Washington, v. 94, p. 902-947.

Bayer, F.M., 1990, A new isidid octocoral (Anthozoa: Gorgonacea) from New Caledonia, with descriptions of other new species from elsewhere in the Pacific Ocean: Proceedings of the Biological Society of Washington, v. 103 , p. $205-228$.

Bayer, F.M., and Stefani, J., 1987, New and previously known taxa of isidid octocorals (Coelenterata: Gorgonacea), partly from Antarctic waters: Proceedings of the Biological Society of Washington, v. 100, p. 937-991.

Bøggild, O.B., 1930, The shell structure of the mollusks: Kongelige Danske Videnskabernes Selskabs Skrifter, Naturvidenskabelig og Mathematiske Afhandlinger, v. 2, p. 231-325.

Borszcz, T., Kuklinski, P., and Zatoń, M., 2013, Encrustation patterns on Late Cretaceous (Turonian) echinoids from southern Poland: Facies, v. 59, p. 299-318.

Branco, W., 1885, Ueber einige neue Arten von Graphularia und über tertiäre Belemniten: Zeitschrift der Deutschen Geologischen Gesellschaft, v. 37, p. $422-432$.

Cairns, S.D., 2001, Studies on western Atlantic Octocorallia (Coelenterata: Anthozoa), Part 1: the genus Chrysogorgia Duchassaing \& Michelotti, 1864: Proceedings of the Biological Society of Washington, v. 114, p. 746-787.

Cairns, S.D., and Cordeiro, R.T.S., 2017, A new genus and species of golden coral (Anthozoa, Octocorallia, Chrysogorgiidae) from the northwest Atlantic: ZooKeys, v. 668, p. 1-10.

Cordeiro, R.T.S., Cairns, S.D., and Perez, C.D., 2017, A revision of the genus Radicipes Stearns, 1883 (Anthozoa: Octocorallia: Chrysogorgiidae): Zootaxa, v. 4319, p. 1-26.

Dautova, T.N., 2018, Deep-water Octocorallia (Cnidaria: Anthozoa) of the temperate northern Pacific: notes on the distribution and new bathyal-abyssal taxa from the Sea of Okhotsk: Deep Sea Research Part II: Topical Studies in Oceanography, v. 154, p. 74-86.

de Moura Neves, B., Edinger, E., and Hayes, V.W., 2018, Morphology and composition of the internal axis in two morphologically contrasting deepwater sea pens (Cnidaria: Octocorallia): Journal of Natural History, v. 52, p. 659-685.

Duchassaing, P., and Michelotti, J., 1864, Supplément au mémoire sur les coralliaires des Antilles: Memorie della Reale Accademia della Scienze di Torino, ser. 2, v. 23, p. 1-23.

Duenas, L.F., Alderslade, P.A., and Sánchez, J.A., 2014, Molecular systematics of the deep-sea bamboo corals (Octocorallia: Isididae: Keratoisidinae) from New Zealand with descriptions of two new species of Keratoisis: Molecular Phylogenetics and Evolution, v. 74, p. 15-28.

Durham, J.W., 1944, Megafaunal zones of the Oligocene of northwestern Washington: University of California Publications, Bulletin of the Department of Geological Sciences, v. 27, p. 101-212. 
Eagle, M.K., 2007, New fossil crinoids (Articulata: Comatulida) from the late Oligocene of the Pentland Hills and Hurstlea, south Canterbury, New Zealand: Records of the Auckland Museum, v. 44, p. 85-110.

Ehrenberg, C.G., 1834, Beiträge zur physiologischen Kenntniss der Corallenthiere im allgemeinen, und besonders des rothen Meeres, nebst einem Versuche zur physiologischen Systematik derselben: Abhandlungen der Königlichen Akademie der Wissenschaften, Berlin, v. 1, p. 225-380.

Esper, E.J.C., 1788-1830, Die Pflanzenthiere in Abbildung nach der Natur mit Farben erleuchtet nebst Beschreibungen [17 Lieferungen in 3 Theilen]: Nürnberg, Raspische Buchhandlung, Erste Lieferung [1788], p. 1-40.

Etnoyer, P.J., 2008, A new species of Isidella bamboo coral (Octocorallia: Alcyonacea: Isididae) from northeast Pacific seamounts: Proceedings of the Biological Society of Washington, v. 121, p. 541-553.

France, S.C., 2007, Genetic analysis of bamboo corals (Cnidaria: Octocorallia: Isididae): does lack of colony branching distinguish Lepidisis from Keratoisis?: Bulletin of Marine Science, v. 81, p. 323-333.

García-Cárdenas, F.J., Núñez-Flores, M., and López-González, P.J., 2020, Molecular phylogeny and divergence time estimates in pennatulaceans (Cnidaria: Octocorallia: Pennatulacea): Scientia Marina, v. 80, p. 317-330.

Giammona, C.P., and Stanton, R.J., Jr., 1980, Octocorals from the middle Eocene Stone City Formation, Texas: Journal of Paleontology, v. 54, p. 71-80.

Glaessner, M.F., and Wade, M., 1966, The late Precambrian fossils from Ediacara, South Australia: Palaeontology, v. 9, p. 599-628.

Goedert, J.L., 1995, First fossil record for Myonera (Bivalvia: Cuspidariidae): The Veliger, v. 38, p. 271-272.

Goedert, J.L., and Campbell, K.A., 1995, An early Oligocene chemosynthetic community from the Makah Formation, northwestern Olympic Peninsula, Washington: The Veliger, v. 38, p. 22-29.

Goedert, J.L., Squires, R.L., and Barnes, L.G., 1995, Paleoecology of whale-fall habitats from deep-water Oligocene rocks, Olympic Peninsula, Washington State: Palaeogeography, Palaeoclimatology, Palaeoecology, v. 118, p. $151-158$.

Grasshoff, M., 1999, The shallow water gorgonians of New Caledonia and adjacent islands (Coelenterata: Octocorallia): Senckenbergiana Biologica, v. 78, p. 1-245.

Grasshoff, M., and Scheer, G., 1991, Die Publikationsdaten von E.J.C. Esper "Die Pflanzenthiere": Senckenbergiana Biologica, v. 71, p. 191-208.

Gray, J.E., 1858, Synopsis of the families and genera of axiferous zoophytes of barked corals: Proceedings of the Zoological Society of London, v. 1857, p. $278-294$.

Gray, J.E., 1870, Catalogue of the Lithophytes of Stony Corals in the Collection of the British Museum: London, British Museum, 40 p.

Greathead, C.F., Donnan, D.F., Mair, J.M., and Saunders, G.R., 2007, The sea pens Virgularia miribilis, Pennatula phosphorea, and Funiculina quadrangularis: distribution and conservation issues in Scottish waters: Journal of the Marine Biological Association of the United Kingdom, v. 87, p. $1095-1103$.

Haeckel, E., 1866, Generelle Morphologie der Organismen. Allgemeine Grundzüge der Organischen Formen-Wissenschaft, Mechanisch Begründet durch die von Charles Darwin Reformirte Descendenz-Theorie: Berlin, Georg Reimer, 574 p.

Häntzschel, W., 1958, Oktokoralle oder Lebensspur?: Mitteilungen aus dem Geologisch-Paläontologischen Institut der Universität Hamburg, v. 27, p. 77-87.

Hayward, B.W., 1977, Lower Miocene corals from the Waitakere Ranges, North Auckland, New Zealand: Journal of the Royal Society of New Zealand, v. 7, p. 99-111.

Hickson, S.J., 1938, An alcyonarian from the Eocene of Mississippi: Journal of the Washington Academy of Science, v. 28, p. 49-51.

Jenkins, R.J.F., 1985, The enigmatic Ediacaran (late Precambrian) genus Rangea and related forms: Paleobiology, v. 11, p. 336-355.

Kiel, S., and Goedert, J.L., 2006, Deep-sea food bonanzas: early Cenozoic whale-fall communities resemble wood-fall rather than seep communities: Proceedings of the Royal Society B, v. 273, p. 2625-2631.

Kiel, S., Kahl, W.-A., and Goedert, J.L., 2012, Traces of the bone-eating annelid Osedax in Oligocene whale teeth and fish bones: Paläontologische Zeitschrift, v. 87, p. 161-167.

Kocurko, M.J., 1988, Notes on fossil octocorals and comparisons of some modern and ancient octocoral remains: Tulane Studies in Geology and Paleontology, v. 21, p. 105-115.

Kocurko, M.J., 1993, Eunicella sp., Octocorallia from the Red Bluff Formation, lower Oligocene, Mississippi: Tulane Studies in Geology and Paleontology, v. 26 , p. 35-39.

Kocurko, M.J., and Kocurko, D.J., 1992, Fossil Octocorallia of the Red Bluff Formation, lower Oligocene, Mississippi: Journal of Paleontology, v. 66, p. 594-602.

Kükenthal, W., 1915, System und Stammesgeschichte der Isididae: Zoologischer Anzeiger, v. 46, p. 116-126.
Kurita, H., 2004, Paleogene dinoflagellate cyst biostratigraphy of northern Japan: Micropaleontology, v. 50, p. 3-50.

Lamouroux, J.V.F., 1812, Extrait d'un mémoire sur la classification des polypiers coralligènes non entièrement pierreux: Nouveau Bulletin des Sciences, par la Société Philomatique, Paris, v. 3, no. 63, p. 181-188.

Lamouroux, J.V.F., 1816, Histoire des polypiers coralligènes flexibles, vulgairement nommés Zoophytes. A Caen, De l'Imprimerie du F. Poisson, p. 1-84, $1-560$.

Langer, M., 1989, Haftorgan, Internodien und Sclerite von Keratoisis melitensis (Goldfuss, 1826) (Octocorallia) in den Pliozänen Foraminiferenmergeln (»Trubi«) von Milazzo (Sizilien): Paläontologische Zeitschrift, v. 63, p. 15-24.

Lauridsen, B.W., and Bjerager, M., 2014, Danian cold-water corals from the Baunekule facies, Faxe Formation, Denmark: a rare taphonomic window of a coral mound flank habitat: Lethaia, v. 47, p. 437-455.

Löser, H., 2015, Die Gattung Moltkia (Gorgonacea, Cnidaria) in der sächsischen Oberkreide (Deutschland): Geologica Saxonica-Journal of Central European Geology, v. 60, p. 427-434.

McCoy, F., 1877, Prodromus of the Palaeontology of Victoria, or, Figures and Descriptions of Victorian Organic Remains. Decade V: Melbourne, Geological Survey of Victoria, $41 \mathrm{p}$.

McFadden, C.S., Quattrini, A.M., Brugler, M.R., Cowman, P.F., Dueñas, L.F., Kitahara, M.V., Paz-García, D.A., Reimer, J.D., and Rodríguez, E., 2021, Phylogenomics, origin, and diversification of anthozoans (phylum Cnidaria): Systematic Biology, v. 70, p. 635-647.

Małecki, J., 1982, Bases of Upper Cretaceous octocorals from Poland: Acta Palaeontologica Polonica, v. 27, p. 65-75.

Mel'nikov, M.E., Pletnev, S.P., Basov, I.A., Punina, T.A., Pulyaeva, I.A., Sedsysheva, T.E., Khudik, V.D., Khulapova, T.N., and Zakharov, Yu.D., 2006, New geological and paleontological data on Federov Guyot (Magellan Seamounts, Pacific Ocean): Pacific Geology, v. 25, p. 3-13. [in Russian]

Milne-Edwards, H., 1857, Histoire Naturelle des Coralliaires ou Polypes Proprement Dits: Librairie Encyclopédique de Roret, Paris, v. 1, p. 1-326.

Milne-Edwards, H., and Haime, J., 1850, A monograph of the British fossil corals. First part, introduction, corals from the Tertiary and Cretaceous formations: Palaeontographical Society, v. 4, 322 p.

Moore, E.J., 1963, Miocene marine mollusks from the Astoria Formation in Oregon: U.S. Geological Survey Professional Paper 419, p. 1-109.

Moseley, H.N., 1876, On the structure and relations of the alcyonarian Heliopora caerulea, with some account of the anatomy of a species of Sarcophyton, notes on the structure of species of the genera Millepora, Pocillopora and Stylaster, and remarks on the affinities of certain Palaeozoic corals: Philosophical Transactions of the Royal Society of London, v. 166, p. 91-129.

Nesbitt, E.A., Martin, R.A., Carroll, N.P., and Grieff, J., 2010, Reassessment of the Zemorrian foraminiferal stage and Juanian molluscan stage north of the Olympic Mountains, Washington State and Vancouver Island: Newsletter on Stratigraphy, v. 43, p. 275-291.

Nielsen, B.K., 1917, Heliopora incrustans nov. sp. with a survey of the Octocorallia in the deposits of the Danian of Denmark: Meddelelser fra Dansk Geologisk Forening, v. 5, p. 3-13.

Nomland, J.O., 1916, Corals from the Cretaceous and Tertiary of California and Oregon: University of California Publications Bulletin of the Department of Geology, v. 9 p. 59-76.

Ott, F.D., 1989, A bibliographical contribution to our appreciation of E.J.C. Esper's Die Pflanzenthiere in Abbildungen nach der Natur (1788-1830) and its Fortsetzungen (1794-1806): Taxon, v. 38, p. 204-215.

Ott, F.D., 1995, The taxa depicted in E.J.C. Esper's "Die Pflanzenthiere in Abbildungen nach der Natur" (1788-1830) and its "Fortsetzungen" (1794-1806) with a combined index to both works: Annalen des Naturhistorischen Museum in Wien, v. 97B, p. 1-36.

Pante, E., and Watling, L., 2011, Chrysogorgia from the New England and Corner seamounts: Atlantic-Pacific connections: Journal of the Marine Biological Association of the United Kingdom, v. 92, p. 911-927.

Pante, E., France, S.C., Couloux, A., Cruaud, C., McFadden, C.S., Samadi, S., and Watling, L., 2012, Deep-sea origin and in-situ diversification of chrysogorgiid octocorals: PLoS ONE, v. 7, e38357. https://doi.org/10.1371/ journal.pone.0038357.

Park, E., Hwang, D.-S., Lee, J.-S., Song, J.-I., Seo, T.-K., and Won, Y.-J., 2012, Estimation of divergence times in cnidarian evolution based on mitochondrial protein-coding genes and the fossil record: Molecular Phylogenetics and Evolution, v. 62, p. 329-345.

Pease, M.H., Jr., and Hoover, L., 1957, Geology of the Doty-Minot Peak area, Washington: U.S. Geological Survey Oil and Gas Investigations Map OM188 , scale 1:62,500, 1 sheet.

Prothero, D.R., and Armentrout, J.M., 1985, Magnetic correlation of the Lincoln Creek Formation, Washington: implications for the age of the Eocene/Oligocene boundary: Geology, v. 13, p. 208-211.

Prothero, D.R., Jaquette, C.D., and Armentrout, J.M., 2001a, Magnetic stratigraphy of the upper Eocene-upper Oligocene Lincoln Creek Formation, 
Porter Bluffs, Washington, in Prothero, D.R., ed., Magnetic Stratigraphy of the Pacific Coast Cenozoic: Pacific Section, Society for Sedimentary Geology, Book 91, p. 169-178.

Prothero, D.R., Streig, A., and Burns, C., 2001b, Magnetic stratigraphy and tectonic rotation of the upper Oligocene Pysht Formation, Clallam County, Washington. in Prothero, D.R., ed., Magnetic Stratigraphy of the Pacific Coast Cenozoic: Pacific Section, Society for Sedimentary Geology, Book 91, p. 224-241.

Quattrini, A.M., Rodríguez, E., Faircloth, B.C., Cowman, P.F., Brugler, M.R., Farfan, G.A., Hellberg, M.E., Kitahara, M.V., Morrison, C.L., Paz-García, D.A., Reimer, J.D., and McFadden, C.S., 2020, Palaeoclimate ocean conditions shaped the evolution of corals and their skeletons through deep time: Nature Ecology \& Evolution, v. 4, p. 1531-1538.

Rathbun, M.J., 1926, The fossil stalk-eyed Crustacea of the Pacific Slope of North America: United States National Museum Bulletin, v. 138, p. 1-155.

Rau, W.W., 1964, Foraminifera from the northern Olympic Peninsula, Washington: U.S. Geological Survey Professional Paper 374-G, p. 1-33.

Rau, W.W., 1966, Stratigraphy and Foraminifera of the Satsop River area, southern Olympic Peninsula, Washington: State of Washington, Division of Mines and Geology Bulletin 53, p. 1-66.

Reich, M., and Kutscher, M., 2011, Sea pens (Octocorallia: Pennatulacea) from the Late Cretaceous of northern Germany: Journal of Paleontology, v. 85, p. 1042-1051.

Sato, S., 1972, Palynological consideration on Tertiary marine sediments of Hokkaido, compared with animal faunas: Journal of the Faculty of Science, Hokkaido University, ser. 4, Geology and Mineralogy, v. 15, p. 217-271.

Schlagintweit, F., and Gawlick, H.-J., 2009, The incertae sedis Carpathoporella Dragastan, 1995, from the Lower Cretaceous of Albania: skeletal elements (sclerites, internodes/branches, holdfasts) of colonial octocorals: Facies, v. 55, p. 553-573.

Serrato Marks, G., LaVigne, M., Hill, T.M., Sauthoff, W., Guilderson, T.P., Roark, E.B., Dunbar, R.B., and Horner, T.J., 2017, Reproducibility of $\mathrm{Ba} / \mathrm{Ca}$ variations recorded by northeast Pacific bamboo corals: Paleoceanography, v. 32, p. 966-979.

Shapiro, E.A., and Ramsdell, R.C., 1965, A pennatulid species, Graphularia ambigua (Morton), from the Upper Cretaceous and lower Tertiary sediments of the Atlantic and Gulf Coastal Plain: Notulae Naturae, v. 373, p. 1-7.

Shimokawara, T., 1963, Geology and structural development of the Yūbari coalfield, Hokkaido, Japan: Geological Section, The Hokkaido Association of Coal Mining Technologists, Sapporo, Japan, Studies on Coal Geology 5, p. 1-243. [in Japanese]

Smith, A.M., and Spencer, H.G., 2016, Skeletal mineralogy of scaphopods: an unusual uniformity: Journal of Molluscan Studies, v. 82, p. 344-348.

Snavely, P.D., Jr., Niem, A.R., Macleod, N.S., Pearl, J.E., and Rau, W.W., 1980, Makah Formation-a deep-marginal-basin sequence of late Eocene and Oligocene age in the northwestern Olympic Peninsula, Washington: U.S. Geological Survey Professional Paper 1162-B, p. 1-28.

Squires, D.F., 1958, The Cretaceous and Tertiary corals of New Zealand: New Zealand Geological Survey Paleontological Bulletin 29, p. 1-107.

Squires, R.L., 1999, Upper Paleocene to lower Eocene ("Meganos Stage") marine megafossils in the uppermost Santa Susana Formation, Simi Valley, southern California: Natural History Museum of Los Angeles County, Contributions in Science, v. 479, p. 1-38.

Squires, R.L., and Demetrion, R., 1992, Paleontology of the Eocene Bateque Formation, Baja California Sur, Mexico: Natural History Museum of Los Angeles County, Contributions in Science, v. 434, p. 1-55.

Squires, R.L., and Goedert, J.L., 1994, A new species of the volutid gastropod Fulgoraria (Musashia) from the Oligocene of Washington: The Veliger, v. 37 , p. $400-409$.

Stearns, R.E.C., 1883, Descriptions of a new genus and species of alcyonoid polyp, from Japanese waters, with remarks on the structure and habits of related forms, etc. : Proceedings of the U.S. National Museum, v. 6, p. 96-101.

Stolarski, J., 1996, Paleogene corals from Seymour Island, Antarctic Peninsula: Palaeontologia Polonica, v. 55, p. 51-63.

Tate, R., 1877, On a new species of Belemnites and Salenia from the middle Tertiaries of South Australia: Quarterly Journal of the Geological Society of London, v. 33, p. 256-259.

Veron, J.E.N., Odorico, D.M., Chen, C.A., and Miller, D.J., 1996, Reassessing evolutionary relationships of scleractinian corals: Coral Reefs, v. 15, p. 1-9.

Verrill, A.E., 1866, Synopsis of the polyps and corals of the North Pacific Exploring Expedition, under Commodore C. Ringgold and Captain John Rogers, USN, from 1853 to 1856 . Collected by Dr. Wm. Stimpson, naturalist of the Expedition. With description of some additional species from the west coast of North America. XII, Part II, Alcyonaria: Communications Read Before the Essex Institute, 1864-1865, Salem, v. 4, p. 181-196.

Verrill, A.E., 1883, Report on the Anthozoa, and on some additional material dredged by the Blake in 1877-1879, and by the U.S. Fish Commission steamer "Fish Hawk" in 1880-1882: Bulletin of the Museum of Comparative Zoology at Harvard College, v. 11, p. 1-72.
Voigt, E., 1958, Untersuchungen an Oktokorallen aus der oberen Kreide: Mitteilungen aus dem Geologischen Staatsinstitut Hamburg, v. 27, p. 5-49.

Waggoner, B., and Collins, A.G., 2004, Reductio ad absurdum: testing the evolutionary relationships of Ediacaran and Paleozoic problematic fossils using molecular divergence dates: Journal of Paleontology, v. 78, p. $51-61$.

Williams, G.C., 1999, Index Pennatulacea. Annotated bibliography and indexes of sea pens (Coelenterata: Octocorallia) of the world 1469-1999: Proceedings of the California Academy of Sciences, v. 51, p. 19-103.

Williams, G.C., 2011, The global diversity of sea pens (Cnidaria: Octocorallia: Pennatulacea): PloS ONE, v. 6, e22747. https://doi.org/10.1371/journal. pone.0022747.

Wright, E.P., 1869, On a new genus of Gorgonidae from Portugal: The Annals and Magazine of Natural History; Zoology, Botany, and Geology, ser. 4, v. 3, p. 23-26.

Yabe, H., 1955, The second discovery of Graphularia-like bodies, from the Tertiary of Japan: Proceedings of the Japan Academy, v. 31, p. 288-293.

Yabe, H, and Sugiyama, T., 1937, On a Graphularia-like fossil from the Pleistocene Tokyo beds of Tokyo: Journal of the Geological Society of Japan, v. 44 , p. $1227-1230$.

Yang, S.-Y., Reimer, J.D., and Low, M.E.Y., 2014, Die Pflanzenthiere in Abbildungen nach der Natur and its Fortsetzungen by Eugenius Johann Cristoph Esper: overlooked sources for its dates of publication and location of type material: Sherbornia, v. 1, p. 5-7.

Zakharov, Yu.D., Pletnev, S.P., Mel'nikov, M.E., Smyshlyaeva, O.P., Khudik, V.D., Evseev, G.A., Punina, T.A., Safronov, P.P., and Popov, A.M., 2007, The first finds of Cretaceous belemnites from the Magellan Rise, Pacific Ocean: Russian Journal of Pacific Geology, v. 1, p. 29-41.

Žítt, J., and Nekvasilová, O., 1993, Octocoral encrusters of rock substrates in the Upper Cretaceous of Bohemia: Casopis pro Mineralogii a Geologii, v. 38, p. $71-75$

\section{Appendix: Localities cited}

UWBM IP B9490.- - Lower part of the Pysht Formation, late? Oligocene. Thin conglomerate layer made up of broken, crushed, and abraded invertebrates, reworked concretions, rip-up clasts, and cetacean bones exposed on point on south shore of the Strait of Juan de Fuca, 675 m west of the eastern edge of Sec. 19, T.31N., R.9W., Clallam County, Washington. GPS coordinates: $48.16126^{\circ} \mathrm{N}, 123.88029^{\circ} \mathrm{W}$. Collectors: J.L. and G.H. Goedert, 30 July 1983.

UWBM IP B9491.-- Lower part of the Pysht Formation, late? Oligocene. Float from strata with some contorted bedding, just below a sequence of thin-bedded turbidites(?), from beach $\sim 565 \mathrm{~m}$ west of the eastern edge of Sec. 19, T.31N., R.9W., Clallam County, Washington. GPS coordinates: $48.15971^{\circ} \mathrm{N}$, 123.87912 W. Collector: J.L. Goedert, 17 April 2006.

UWBM IP B9492.- - Lower part of the Pysht Formation, late? Oligocene. Cliff along beach, just northwest of old WWII observation post, Sec. 19, T.31N., R.9W., Clallam County, Washington. GPS coordinates: $48.15969^{\circ} \mathrm{N}, 123.89223^{\circ} \mathrm{W}$ Collector: J.L. Goedert, 26 May 2020.

UWBM IP B9493.-Lincoln Creek Formation, late Eoceneearly Oligocene. Roadcut on north side of the BrooklynOakville road, SW $1 / 4$ SW $1 \frac{1}{4}$ Sec. 12, T.15N., R.6W., Grays Harbor County, Washington. GPS coordinates: $46.79288^{\circ} \mathrm{N}$, $123.38820^{\circ} \mathrm{W}$. Collectors: L.S. Guthrie and J.L. Goedert, 1 July 2020 .

UWBM IP B9494.-Pysht Formation, late Oligocene. Float, nodule from slumped mudstone in toe of landslide, extreme southwestern corner of Sec. 19, T.31N., R.9W., Clallam 
County, Washington. GPS coordinates: $48.160316^{\circ} \mathrm{N}$, 123.921031 ${ }^{\circ} \mathrm{W}$. Collector: T. Iversen, 2018.

UWBM IP B9495.-Lincoln Creek Formation, late Eoceneearly Oligocene. Roadcut in SE1/4 Sec. 10, T.17N., R.5W., near Malone, Grays Harbor County, Washington. GPS coordinates: $46.970256^{\circ} \mathrm{N}, 123.289007^{\circ}$ W. Collector: J.L. Goedert, 2012.

UWBM IP B9496.- - Lincoln Creek Formation, late Eoceneearly Oligocene. East bank of Porter Creek, SW11/4 of Sec. 11, T.17N., R.5W., Grays Harbor County, Washington. GPS coordinates: $46.9694^{\circ} \mathrm{N}, 123.2775^{\circ} \mathrm{W}$. Collectors: J.L. and G.H. Goedert, 16 September 1995.

UWBM IP B9497.-Makah Formation, early Oligocene. Concretion found as float on beach terrace $\sim 350$ meters northwest of the mouth of the Sekiu River, NE¹/4 Sec. 8, T.32N., R.13W., Clallam County, Washington. GPS coordinates: 48.2914 ${ }^{\circ}$ N, $124.3991^{\circ}$ W. Collector: J. L. Goedert, 29 April 2009.

Accepted: 23 January 2022 